\title{
Mercosur: Limits of Regional Integration
}

\author{
Ricardo Caichiolo*
}

\section{Abstract}

This study is focused on the evaluation of successes and failures of the Common Market of the South (Mercosur). This analysis of Mercosur's integration seeks to identify the reasons why the bloc has stagnated in an incomplete customs union condition, although it was originally created to achieve a common market status. To understand the evolution of Mercosur, the study offers some thoughts about the role of the European Union (EU) as a model for regional integration. Although an EU-style integration has served as a model, it does not necessarily set the standards by which integration can be measured as we analyse other integration efforts. However, the case of Mercosur is emblematic: during its initial years, Mercosur specifically received EU technical assistance to promote integration according to EU-style integration. Its main original goal was to become a common market, but so far, almost thirty years after its creation, it remains an imperfect customs union.

The article demonstrates the extent to which almost thirty years of integration in South America could be considered a failure, which would be one more in a list of previous attempts of integration in Latin America, since the 1960s. Whether it is a failure or not, it is impossible to envisage EUstyle economic and political integration in South America in the foreseeable future. So far, member states, including Brazil, which could supposedly become the engine of economic and political integration in South America, have remained sceptical about the possibility of integrating further politically and economically. As member states suffer political and economic turmoil, they have concentrated on domestic recovery before being able to dedicate sufficient time and energy to being at the forefront of integration.

Keywords: Mercosur, European Union, regionalism, integration, international organisation

\section{Introduction}

Rapid changes have intervened during the last few decades in the structure and development of international organisations. Old ideas of ensuring human freedom, dignity and welfare are still the core foundations of international organisations and of improving the relationship of one country with another. The idea of uni-

Ricardo Caichiolo, PhD (Université catholique de Louvain, Belgium) is legal and legislative adviser to the Brazilian Senate and professor and coordinator of the post graduate programs on Public Policy, Government Relations and Law at Ibmec (Instituto Brasileiro de Mercado de Capitais, Brazil) versality is seen as the source of the solidification and enforcement of these values. However, the concept of universality has also been linked to the idea of regionalism, both regarded as being complementary concepts geared towards the improvement of international organisations as well as to society itself.

Another significant development that is seen from the international community is the emergence and attention of supranational organisations as well as the importance they hold towards their respective organisations or state. Although there are times wherein national dependencies matter, the role of supranational organisations, in certain cases, may go beyond that of the state itself. This can be seen from the influence and level of authoritative power as well as the autonomy that they enjoy, from intra- and interregional organisations. Besides, within the context of regionalism, member nations or involved parties are geared towards developing intergovernmental organisations that can operate and manage the regional cooperation, treaties, agreements and the number of accords being entered into by involved parties. The existence of these intra- and interregional organisations is vital since it is within their activities or goals that the fulfilment of key objectives, the development and the success of regional integration, lies.

Before the actual establishment of Mercosur in the 1990s, there had been several attempts at achieving both regional and economic integration among the Latin American nations. The first were the Latin American Free Trade Association (LAFTA), in 1960, the Latin American Common Market (LACM), in 1965, and the Latin American Integration Association (LAIA), in 1980. All of these were categorised as failures for various substantial reasons and for failing to achieve consensus. However, in 1991, the Treaty of Asunción (TA) finally paved the way for the establishment of Mercosur, which then represented the Southern Cone Common Market. The initial members of the subregional common market were Argentina, Brazil, Paraguay and Uruguay. Their cooperation has been marked as historic because these countries had been involved in regional wars during the 20th century. More than twenty years later, in July 2012, Venezuela became a full member state; however, on 1 December 2016, it was suspended from Mercosur as it failed to respect human rights and to meet a fouryear deadline to fully adapt to the trade bloc regulations required for membership. Bolivia is moving closer to becoming the newest full member, according to the Adhesion Protocol signed on 15 July 2015, which can be 
considered as a new step towards the enlargement of Mercosur. ${ }^{1}$ Ecuador is expected to be next in line.

It remains to be seen whether such an enlargement can help promote regional integration. So far, member states, especially Brazil, have clearly preferred enlargement vis-à-vis the deepening of integration. This article will next present some historical and institutional aspects concerning the creation of Mercosur and how the EU served as a model for integration.

\section{Mercosur's History of Integration}

Less than a decade after the first efforts towards integration in Europe began, during the 1950s, Latin American countries decided to follow a similar path, being stimulated by insightful information coming from the Economic Commission for Latin America and the Caribbean (ECLAC). The creation of the Latin American Free Trade Association (LAFTA), ${ }^{2}$ through the signing of the Treaty of Montevideo I in 1960, marked a crucial moment in the history of integration in Latin America.

Twenty years later, in 1980, with the signing of the Treaty of Montevideo II, the Latin American Association for Integration (LAIA) was established to replace LAFTA. The Treaty of Montevideo I that created LAFTA was originally signed by Argentina, Brazil, Chile, Mexico, Paraguay, Peru and Uruguay. Colombia and Ecuador joined the group in 1961, Venezuela in 1966 and Bolivia in 1967.

The ultimate and ambitious goal had been, according to the Treaty, to move towards the 'establishment of a Latin-American common market, ${ }^{3}$ in a gradual and progressive way'.

As a first step, the Treaty established a free trade zone, setting a deadline of twelve years within which to implement a programme for trade liberalisation, envisaging the dismantling of tariff barriers. Article 3 of the Treaty also defined some directives in its implementation, such as pluralism, convergence and reciprocity. Referring to pluralism, the Treaty underlined that the will of member countries should sustain the need to integrate over and above the diversity, which might exist in political and economic matters in the region. Convergence, that is, progressive multilateralization of partial scope agreements, can be achieved by means of periodical negotiations between member countries. Regarding reciprocity,

1. The protocol of admission defines the different stages and commitment to reach the full incorporation of Bolivia into Mercosur. The admission as a full member will take place once the Legislatives of the other member states of Mercosur ratify the protocol. So far, Uruguay (17 May 2017) and Paraguay (13 August 2018) have deposited their instrument of ratification.

2. Others efforts of integration processes started during the 1960 s and 1970s: the Central American Common Market (CACM) in 1960, the Andean Pact (later CAN) in 1969 and the Caribbean Community (CARICOM) in 1973.

3. Source: http://wits.worldbank.org/GPTAD/PDF/archive/LAIA-ALA DI pdf. member countries should expand their imports to the same extent that their exports increase.

Although LAFTA, in its initial years, stimulated trade among member countries, these principles had been overlooked. At the end of the 1960s, LAFTA became obsolete since member countries had not complied with several principles, including those previously mentioned. Items eligible on the common lists for preferential treatment had never been fully liberalised; access to markets had been unequally distributed; institutions to monitor and enforce reciprocity had not been created; most of the bilateral agreements were restricted to the Big Three (Argentina, Brazil and Mexico). The other two groups that were led by Chile, Colombia and Venezuela (the middle group), and Bolivia, Ecuador and Paraguay (the least-developed economies), had started to complain about the agreement because the benefits of integration mostly favoured the Big Three. ${ }^{4}$ Disappointment with such a scenario had expedited the formation of the foundation of the Andean Group within LAFTA in $1969 .^{5}$

In addition, the role of ECLAC, which had initially guided the process of integration, had consisted of preventing any possibility of success. Guidelines from ECLAC to the Third World had consisted of the adoption of strategies of import substitution industrialisation (ISI) and protectionist policies. ${ }^{6}$ The intention had been to create and strengthen an internal market that would lead to development and self-sufficiency. However, several courses of action had been undertaken at the time, which were felt to be essential in order to achieve this goal. Instead, they created a negative impact in the integration process. These undertakings included nationalisation, subsidisation of industries, augmented taxation and highly protectionist trade policies.

Argentina, Brazil and Mexico had adopted the strategy of ISI, a policy that was obviously dissimilar to the process of integration that LAFTA proposed. Referring to the Brazilian perception of the integration process at the time, Vaz affirmed that:

the Brazilian resistance to the creation of a common market was demonstrated since the late 1950 s and it remained throughout the trajectory of LAFTA ... it reflected ... the option for autonomy in promoting

4. D.D. Paiva \& M.B. Braga, 'Integração econômica regional e desenvolvimento econômico: reflexões sobre a experiência latino-americana', 9(16) Revista de Desenvolvimento Econômico 61-71 (2007).

5. The Andean Group (predecessor of the Andean Community) was created with the signature of its founding treaty, the Cartagena Agreement, by five countries: Bolivia, Colombia, Chile, Ecuador and Peru. Venezuela joined the group in 1973, while Chile left it in 1976. Another important subregional experience created during the 1960s was the Central American Common Market (CACM). The Treaty of Managua was signed in 1960 by El Salvador, Guatemala, Honduras and Nicaragua, while Costa Rica joined the bloc in 1963. In: R.J. Langhammer \& U. Hiemenz, 'The Rationale of Regional Integration Among Developing Countries', 1 International Economic Integration, Critical Perspectives on the World Economy (1998).

6. W. Baer, 'Import Substitution and Industrialization in Latin America: Experiences and Interpretations', 7(1) Latin American Research Review 95-122 (1972 Spring). 
economic development, guided then by the import substitution model. ${ }^{7}$

Finally, several countries in Latin America had military governments, whose outlook had been predominantly against making concessions that affected national sovereignty.

LAIA tried to learn from the mistakes made by its predecessor. Although Article 1 of the Treaty of Montevideo II decrees that ' $[\mathrm{t}]$ he long-term objective of such a process shall be the gradual and progressive establishment of a Latin American common market', in practice this is not an achievable goal. LAIA is more realistic and less ambitious. ${ }^{8}$ At the same time, the Treaty underlines that member countries may decide 'to renew the LatinAmerican integration process and to establish objectives and mechanisms compatible with the reality of the region'. ${ }^{9}$ In addition, LAIA defines in Article 3 the principles that should guide the agreement, ${ }^{10}$ which embraces the concept of a system in favour of countries at a relatively less advanced stage of economic development. The institutional and legal framework of LAIA ('umbrella') works as a central record-keeping authority and custodian of bilateral or subregional agreements (including Mercosur). These subregional agreements are composed of benefits and concessions that are restricted to signatories, without being extended to third countries. ${ }^{11}$ Besides, LAIA has limited integration to sectors of production, in a fragmented way - the intention is that not only countries, but also those sectors of production will gradually converge and unite. Three mechanisms were defined to eventually achieve such unity:

a. Regional Tariff Preference, in which member countries shall reciprocally grant a regional tariff preference to be applied with reference to the level in force for third countries and be subject to the corresponding regulation;

b. Regional Scope Agreements, those in which all member countries participate; and

c. Partial Scope Agreements, those in which two or more countries of the area participate.

One important difference between LAFTA and LAIA refers to the partial scope agreements. ${ }^{12}$ According to

7. A.C. Vaz, Cooperação, integração e processo negociador: a construção do Mercosul. Instituto brasileiro de relações internacionais, Brasília (2002), at 59

8. A. Malamud \& P. Schmitter, 'The Experience of European Integration and the Potential for Integration in South America', IBEI Working Paper, CIDOB editions, Barcelona 2007.

9. Treaty of Montevideo II. Source: http://Mercosur.sice.oas.org/trade/ Montev_tr/Montev1e.asp\#chapl. Retrieved on 27June 2019.

10. http://sice.oas.org/trade/Montev_tr/Montev1e.asp\#chapl. Retrieved on 27 June 2019.

11. A. Barbiero \& $Y$. Chaloult, 'O Mercosul e a nova ordem econômica internacional', 44(1) Revista Brasileira de Política Internacional, 22-42 (2001)

12. Article 9 of the Treaty of Montevideo (1980) defines the rules that govern partial scope agreements: a) They shall remain open to adhesion, by previous negotiation of the remaining country-members; b) They shall contain clauses promoting convergence in order that their benefits reach all member countries; c) They may contain clauses promoting the principle of convergence (meaning progressive multilateralization of partial scope agreements by means of periodical negotiations between member countries), it allows member states to establish trade agreements with third countries, both inside and outside the region. In other words, this principle allows all member states of LAIA to take part, if they wish to do so, in all partial scope agreements. As defined in Chapter V Article 27:

At the same time, member countries may draw up partial scope agreements with other developing countries or respective economic integration areas outside Latin America, following the various modalities foreseen in the third section of chapter II of the present Treaty, and under the terms of the pertinent regulative provisions.

The so-called Economic Complementation Agreements (ECAs) lie in the realm of partial scope agreements.

According to Resolution 1 Article 1, adopted by the LAFTA Council of Ministers of Foreign Affairs: 'Contracting Parties shall incorporate into the new integration scheme, the concessions granted in national lists, non-extensive lists and complementation agreements.' These ECAs deal with fixed tariff preference agreements, free-trade agreements and subregional integration agreements. As a subregional integration agreement, Mercosur was protocolised at LAIA through the Partial Scope Economic Complementarity Agreement (PS.ECA) number $18^{13}$ (see Annex I). In order to be protocolised at LAIA, partial scope agreements must be concluded according to the several procedural rules lis- convergence with other Latin American countries, in concurrence with the mechanisms established in the present Treaty; d) They shall include differential treatments depending on the three categories of countries recognized by the present Treaty. The implementation of such treatments as well as negotiation procedures for their periodical revision at the request of any member country which may consider itself at a disadvantage shall be determined in each agreement; e) Tariff reductions may be applied to the same products or tariff sub-items and on the basis of a percentage rebate regarding the tariffs applied to imports originating from non-participating countries; $f$ ) They shall be in force for a minimum term of one year; and g) They may include, among others, specific rules regarding origin, safeguard clauses, non-tariff restrictions, withdrawal of concessions, renegotiation of concessions, denouncement, co-ordination and harmonization of policies. Should these specific rules not have been adopted, the general provisions to be established by member countries on the respective matters shall be taken into account. Source: http://sice.oas.org/trade/Montev_tr/Montev1e. asp\#chapl.

13. The notification of the Treaty of Asunción was made through LAIA, invoking the 'enabling clause'. Other members of the GATT criticised this procedure as they deemed notification via Art. XXIV GATT necessary. 
ted in Article $5^{14}$ of the Resolution 2 adopted by the LAFTA Council of Ministers of Foreign Affairs.

LAIA has incurred much criticism regarding its inability to promote economic integration and increase of trade among its signatories. Unfortunately, during the 1980s, economic and political crises seriously affected the national development strategies of Latin American countries. Currency devaluations and restrictions on imports occurred, which curtailed any kind of integration progress and efforts to coordinate trade policies.

In summary, political and economic conditions during the 1980 s prevented LAIA from advancing towards its objectives. Despite all the criticism against it, LAIA at least promoted orientation concerning the procedural rules to be respected in order to implement trade agreements in the region. As Malamud affirms: $:^{15}$

was slightly more fruitful than its predecessor LAFTA. It simultaneously framed and constituted part of the third wave of regional integration in Latin America, of which Mercosur was to represent the most visible outcome.

Despite such a dismal outcome, LAIA's good intentions, to its credit, are documented and can be found through consultation of the Itamaraty (the Brazilian Ministry of Foreign Affairs) archives. Documents from the permanent Brazilian delegation to the Latin American Integration Association (BRASALADI) show that LAIA has played a highly significant part, mainly concerning negotiations of partial scope agreements and of ECAs, related to either Mercosur or other Latin American countries. Some of these documents have revealed the intention to revitalise Brazil's importance in Latin America and to promote its ties with the region. ${ }^{16}$

Under the LAIA 'umbrella' there are currently forty partial scope agreements of economic complementarity (PS.ECA) in force (Annex I). As previously mentioned, Mercosur was protocolised at LAIA through the PS.ECA 18, as on 26 March 1991, where the signature of the Treaty of Asunción took place, establishing a

14. Among the rules are that negotiations may start, be concluded and executed at any time of the year, and that member states shall notify the Committee, as other member countries may have the intentions and, thus, possibility to participate in it. Negotiations may start thirty days after the date of notification to the Permanent Executive Committee, and technical support of the Secretariat is granted to member states to facilitate negotiations. Signatory member countries of the finished agreement shall forward an authenticated copy to the Committee, which will be immediately distributed to the other member countries. At least once a year, member countries participating in a partial scope agreement shall report to the Committee about the progress attained pursuant to the undersigned commitments; at the same report they must inform about any modification which may substantially change the agreement's text. Source: http://sice.oas.org/trade/Montev_tr/ resolute.asp\#res2. Retrieved on 27 June 2019.

15. A. Malamud, 'Presidential Democracies and Regional Integration. An Institutional Approach to Mercosur (1985-2000)'(European University Institute in Political and Social Sciences, PhD Thesis, Florence, March, p. 53) (2003).

16. The present author made the consultation at the Itamaraty Historical Archive in Brasília (Brazil).
Common Market of the South between the Republics of Argentina, Brazil, Paraguay and Uruguay.

It is not possible, however, to understand the history of Mercosur's integration without referring to its 'founding fathers': the efforts of José Sarney and Raúl Alfonsín, the Presidents of Brazil and Argentina, respectively, represent one of the leading factors that led to the development of the bloc. Their influence can be traced back to their assumed roles as tutors in the establishment of Mercosur after the two countries signed the Declaration of Iguaçu (1985) and entered the Brazil-Argentina Integration and Economics Co-operation Program (PICE) in 1986 (see Annex II - Institutional Landmarks - Mercosur's history of integration). Remarkably, the PICE was instrumental in establishing a partnership between Brazil and Argentina, which saw both casting aside dictatorships and, thereupon, establishing a much broader idea of regional and market integration. ${ }^{17}$

At the time of Mercosur's establishment in 1991, political choices were indeed in favour of achieving a common market by 1994, as reflected in the name given to the bloc, i.e. the Common Market of the South. Democratic regimes from Brazil and Argentina had shared a common perception during the middle 1980s that a regional framework could act as a parallel process to worldwide multilateralization, enabling them to face tasks that would otherwise remain impossible to deal with. ${ }^{18}$ The concept of Mercosur was rooted in the founding treaties of the mid-1980s and the political intent of the then presidents of Brazil and Argentina. Their intensive participation was pivotal in devising a plan to lessen domestic pressures for increased military spending through economic integration. They proposed a progressive state-led initiative, an integration blueprint whose aim was to build a 'true community and not just an (economic) association' ${ }^{19}$

It initially set a progressive Trade Liberalisation Programme, to be in force until 31 December 1994 (the first stage, or the 'period of transition'). The Treaty also previewed the implementation of a customs union and the harmonisation of macroeconomic policies. The institutional structure was composed of two main bodies during the first period: The Common Market Council (CMC) and the Common Market Group (CMG). It contained five annexes: Annex I established the Trade Liberalisation Programme, protocolised in LAIA by the Partial Scope Economic Complementarity Agreement (ECA) 18; Annex II defined a rule of origin for the period of transition towards the customs union (until 1994); Annex III established that any dispute arising between state parties as a result of treaty applications

17. V. Bulmer-Thomas, The Economic History of Latin America since Independence, Cambridge University Press (1994)

18. S. Gratius \& M.G. Saraiva, 'Continental Regionalism: Brazil's Prominent Role in the Americas', CEPS Working Document. No. 374 (February 2013).

19. R. Alfonsín, 'La Integración Sudamericana: Una Cuestión Política', 9(24) Sintesis FUALI, 6 (2001) in A. Malamud, 'Mercosur Turns 15: Between Rising Rhetoric and Declining Achievement', 18(3) Cambridge Review of International Affairs 424 (2005). 
was to be settled by means of direct negotiations; Annex IV safeguards measures; and Annex V provided for the creation of working subgroups.

\section{Mercosur's Legal Foundations and Institutional Framework}

The Treaty of Asunción (1991) was instrumental in the founding of Mercosur and, furthermore, in the addition of two other member countries, namely Paraguay and Uruguay. It laid out the framework on which Mercosur's core institutions were based and later established. It also provided the principles for establishing a common market between the member nations through the elimination of import and export fees. Moreover, the Protocol of Ouro Preto (1994) was significant in improving and reinforcing certain policies included in the Treaty of Asunción (1991), and it was given credit for making the Treaty legal as well as internationally recognised. Needless to say, there were other important treaties and protocols that were signed by the member states, which were needed in order to adjust certain aspects of the regional bloc. This can be attested to in the Protocols of Brasília (1991) and Olivos (2002), in which the focus was to improve the mechanism or procedure for dispute settlement within Mercosur (see Annex III).

The establishment of the CMC and the CMG, as intraorganisations of Mercosur, was the most beneficial and significant aspect that the Treaty of Asunción (1991) laid out. CMC is the highest decision-making body of Mercosur, which comprises the ministers of economy and foreign affairs of all member states. Here all decisions taken must necessarily be unanimous for their effective implementation. Baptista $(2001)^{20}$ shows that apart from decision-making, it is also responsible for seeing to the strategic objectives laid out in the Treaty of Asunción (1991) and in the Ouro Preto Protocol (1994). The active participation of the Ministers in the CMC indicates the progress and projected plans for the future of Mercosur. There are four members and hence only four to eight ministers assemble. ${ }^{21}$ Nowadays, despite the loose links some countries hold within Mercosur, they have the privilege of sending their representative to the CMC as acting officials. Although the $\mathrm{CMC}$ is regarded as being the highest group or organisation within Mercosur, many competencies of the CMC have been delegated to the CMG. The former has tried to maintain and perform its initial function as stated as its raison d'être from the start.

However, in the course of almost three decades, officials heading the CMC have realised that their relative func-

20. L.O. Baptista, MERCOSUR, Its Institutions and Judicial Structure (2001). Source: http://ctrc.sice.oas.org/geograph/south/mstit2_e.pdf.

21. Considering Venezuela's suspension of the bloc since 2016. tion is hindered by critical factors. Despite being the highest organisation within Mercosur, officials are still unable to be independent of certain factors that can influence their decisions. ${ }^{22}$ Officials of the CMC are still government officials who are under the influence of the Presidents of their respective countries. In spite of its highest possible position within Mercosur, this governing body fails to reach a consensus that is worthy of being designated a 'Mercosur decision'. Instead, each decision is still based on pressing issues that each official and his or her respective country is facing, persevering in the hope that Mercosur can be of help to them in order to alleviate or change certain conditions. Despite their efforts, a neutral consensus can be impossible to attain, owing to the practices of the political hierarchy within the CMC itself. The effect is that the CMC is having difficulty in achieving the medium- and longterm strategic agenda of Mercosur, which is considered to be paramount for the success of regional and market integration.

CMG is the executive body, one of whose main tasks is to implement the Council's decisions. Ministers of foreign affairs from all member states control the executive body, thus making it an intergovernmental organ. ${ }^{23}$ They can be seen to be instrumental in that their functions consist of carrying out actions and decisions that are necessary in terms of making Mercosur more legitimate both regionally and internationally through effective governance. While the CMC seeks to fulfil its role in approving or rejecting initiatives from its subgroups, it has the executive power to regulate the decisions made by the CMC and to administer it in order to guarantee that it is working properly and within the context of the integration process. ${ }^{24}$ The CMG is the more crucial and important of the two in terms of functions and the number of negotiations. It could be considered as being the developer of the building blocks, which are necessary for the success of the integration process. The CMG is composed of four incumbent and four alternate members from each country, ${ }^{25}$ with officials coming from the ministries of foreign affairs, economy and the central bank of each county. Given the role and tasks that the CMG needs to fulfil, there are eighteen work subgroups that attend to key areas. There are thirteen specialised assemblies, which focus on diverse issues and twelve ad hoc groups that focus on special issues such as the biotechnology and sugar sectors. ${ }^{26}$ All are headed by national officers from each country.

The sharing of tasks has the goals of organising the workload of the CMG and lessening the problems that are usually associated with public administrations and

22. M. Mecham, 'MERCOSUR: A Failing Development Project?', 79(2) International Affairs 369-387 (2003).

23. Another decision-making body is the Mercosur Trade Commission (MTC), and its main role is to monitor external tariffs and solve traderelated disputes. All three decision-making bodies of Mercosur are intergovernmental.

24. Baptista, above n. 20.

25. Considering Venezuela's suspension of the bloc since 2016

26. To see the current organogram of Mercosur: www.mercosul.gov.br/ images/pdf/Organograma-MSUL.pdf. 
regional integration. This sharing is done through a multiplicity of auxiliary organisations, supposedly allowing the CMG to oversee multiple areas with enough manpower, focus and resources that are critical in policymaking. This set-up is ideal within a regional bloc and makes it easier for Mercosur to address important issues without facing too many problems. However, it also has flaws, which have already been seen or manifested in the CMG and its sub-organisations. ${ }^{27}$

In light of the complex structure of the CMG, the error that can be observed is the lack of cooperation among subgroups, specialised assemblies and ad hoc groups. Owing to the complex structure and the numbers of sub-organisations that CMG needs to manage, cooperation is nearly impossible to attain, eventually leading to work overload and pending issues that are in need of attention. The overall outcome is that this lack of cooperation results in losses, not only financially, but also in the fact that issues are being left without necessary policies or guidelines. In the case of Mercosur, institutions are not as strong as those in the EU: despite the phenomenon of such 'institutional hypertrophy', they lack the autonomy (and budgetary ability) to implement their decisions that will affect all member states. Concentration of power in the presidential realm is a characteristic that can be found at every turn in Mercosur, as we will see later. Most subgroups working under the CMG eventually attain autonomy from other groups, especially if the area of focus is somewhat foreign to the CMG officials. Some of the aforementioned problems exhibit the failure of the CMG, which could explain why the organisation has lost its efficiency over the years.

These two organs, the CMC and the CMG, are considered to be the driving force of the whole regional bloc of Mercosur. As defined by the Treaty of Asunción (1991) and the Protocol of Ouro Preto (1994), their role is to implement the authority required to constantly shape Mercosur as a regional bloc and as a new market for foreign and local investors. However, considering the experience and current position of the regional bloc, it was a must to establish additional and specialised organisations within it. $^{28}$ These organisations deal with issues, policies and tasks that complement the decisions made by the CMG and the CMC. As such, the concept was to lessen the tasks of the CMG and of the CMC and to diffuse the problems that usually arise during the regional integration process, while enhancing work efficiency through careful division of work. Thus, under the Protocol of Ouro Preto (1994), the Mercosur Trade Commission (MTC), ${ }^{29}$ the Mercosur Administrative Secre-

27. Baptista, above n. 20.

28. R. Bouzas \& H. Soltz, 'Institutions and Regional Integration: The Case of MERCOSUR', in V.B. Thomas(ed.), Regional Integration in Latin Ameri$\mathrm{ca}$ and the Caribbean: The Political Economy of Open Regionalism, University of London, The Brookings Institutions (2001) 1-25.

29. Baptista, above n. 20, at 64 emphasises that there are cases of norms emanating from Mercosur bodies that are flawed in their origin because they exceed the limits of the constituting treaties. He provides as an example Decision 9/94, which created the Mercosur Trade Commission: 'According to the Treaty of Asunción (1991), this body could not be tariat (MAS), the Economic and Social Consultative Forum (ESCF) and the Joint Parliamentary Commission (JPC) ${ }^{30}$ were further created to strengthen the decision and policymaking of Mercosur.

However, all of them were not established for the purpose of exercising supranational powers. This limiting factor is to be underlined as marking the main difference between the EU and Mercosur. This was not the only evidence of limitation. The Treaty of Asunción (1991) was influential in defining limitations to all officials and intra-organisations, ensuring that their interests and objectives would not go beyond the established boundaries of their respective member states. Moreover, the Treaty of Asunción (1991) was instrumental in preparing the framework for decision-making, whose basis would always be a major consensus among member states.

Although the implementation of the Treaty of Asuncion had been initially perceived as a promising means of attaining an advanced stage of economic integration, it would prove to be insufficient in achieving this end. Although politically motivated, it did not contain any political expression. Besides, political choices are mutable, especially in more volatile and unstable countries. The 'Golden Age' of Mercosur, from 1991 to 1998, enjoyed increasing flows of foreign direct investments and intra-regional trade. During this period, as Malamud observed,

Total trade of member countries grew from 7 percent of GDP to represent more than 11 percent. Mercosur underpinned this increasing openness of its members' economies: trade between Mercosur-4 and the rest of the world was about 8 times that between the bloc's members in $1990 .{ }^{31}$

However, the end of this age saw member states, even the smaller ones that had so far been more supportive in deepening the integration process, become reluctant. The three-year transition period from 1991 to 1994 had not seen Mercosur evolve into a common market, as had been envisaged. Instead, the Protocol of Ouro Preto bestowed on Mercosur the permanent institutional structure that was a blueprint for a customs union to be in place by 2000. The customs union has remained incomplete to this day.

Concerning the legal provisions in Mercosur, the Treaty of Asunción (1991) originally delineated its institutional framework. The Treaty comprises five annexes that

created by Decision of the Mercosur Council. Consequent objections as to its validity led to its incorporation into the Protocol of Ouro Preto'. In: Baptista, above n. 20.

30. The Joint Parliamentary Commission was substituted by the Parliament of Mercosur, which was established on 6 December 2006. On 7 May 2007, sitting of the Opening Session, when Mercosur parliamentarians took their positions (18 representatives per country, as indicated by their respective national parliaments). See www.parlamentodel MERCOSUR.org.

31. A. Malamud, 'The Internal Agenda of Mercosur: Interdependence, Leadership and Institutionalization', in Los nuevos enfoques de la integración: más allá del regionalism, Grace Jaramillo (Ed.) Quito, FLACSO 120 (2008). 
have codified the following: a transitory method for intrazonal protection; a generalised, straight and automatic programme for the removal of intrazonal charges; schematic rules of origin; groups to work on the management of specific economic policies; and a specific period for the setting up of a conflict resolution mechanism. The traditional interpretation of the Treaty of Asunción suggests that it be a 'framework treaty' to be completed by the secondary legislation that would be filled up or composed of the Mercosur bodies. However, in reality, it has not worked as originally conceived. There are two main reasons for this. First, some of the exhaustive laws, as framed by the Mercosur bodies, for example, the protocols on investment, services or competition, are primary laws rather than secondary ones, primary laws being international treaties simply annexed to the Asunción Treaty and sanctioned using the same methods. Being international treaties, they must follow internalisation procedures and be ratified. Second, the most significant achievement of Mercosur is the functioning of the primary law that removed intrazonal tariffs. On the other hand, the categorisation of certain laws as really being secondary laws in nature has proven to be rather ineffective. Primary laws are mainly international treaties annexed to the Treaty of Asunción, with secondary laws being more a part of Mercosur. With this in mind, the next section focuses on the legal nature of Mercosur's secondary legislations. $^{32}$

\section{Legal Nature of Mercosur's Secondary Legislation}

The legal nature of Mercosur's secondary legislations is not easily determinable. Owing to the ongoing political and academic debates on the characteristics of EU law and regional integration legislation, it is essential to understand the concepts behind EU laws and regional integration. Most of the debates have centred on the idea that EU laws and regional integration laws act as being intermediate between the laws of the individual and the national laws. This leads to confusion while framing laws for the state and subsequently making them applicable to individuals. This brings to the fore one of the major hurdles for regional integration law, namely the framing of legislations for states that will eventually be applicable to individuals. The theory of supranationalism, as a distinct characteristic of European integration, has further added to the confusion. The difference between intergovernmentalism and supranationalism refers to the presence or absence of an inter-

32. R. Bouzas et al., In-Depth Analysis of MERCOSUR Integrations, Its Prospectives and the Effects Thereof on the Market, Access of EU Goods, Services and Investment, Observatory of Globalisation, University of Barcelona - Science Park of Barcelona (November 2002). Source: www.sciencespo.fr/opalc/sites/sciencespo.fr.opalc/files/in-depth \%20analysis\%20of\%20mercosur\%20integration.pdf. national procedure to frame laws that oblige a state, which is separate from a ratification, national acceptance act or internalisation. This has been confused with the matter of the composition of the institutions that frame such laws, on the one hand, and with their legal effects on individuals, on the other. Take the case of the former North America Free Trade Agreement (NAFTA), for example, which was considered an intergovernmental body, owing to the lack of an autonomous body to formulate new laws, wherein any new NAFTA laws or modifications would result in a new Treaty. However, EU Treaties cannot be directly labelled as being supranational in nature. This is because while EU Treaties have a supranational system that can frame laws, the Treaty itself, being an international one (similar to former NAFTA), produces a series of legal obligations on its members without any interference from the supranational organs. ${ }^{33}$

When there are procedures for creating supranational laws, the legal nature is not based on the type of institutions that frame these laws or on the processes that are adopted by these institutions. EU law, which is primarily supranational in nature, does not change in nature because it is the intergovernmental Council that enacts it. Similarly, EU law does not amend itself on the basis of whether the Council works by voting a majority or unanimous decision and remains the same even while it may be the Commission or the Council that is enacting the law. When the framing of integration law is complete and enforced, the question then arises as to its direct application to an individual. Traditionally it is believed that EU law, once framed, becomes directly applicable. However, this is true only with regulations, while the primary laws and directives are not directly applicable. The EU frames laws primarily through regulations in specific fields, such as financial issues, trade policies and agriculture, while in other areas it legislates via directives, as for example in issues related to the reconciliation of domestic legislation. It must be noted that there are legal provisions within the EU that cannot be applied directly to individuals. Instead, they can be used within the level of community or domestic jurisdictions. There are also some laws that fail - only apparently - to produce any direct impact; neither are they directly applicable. In this context it can be stated that EU directives cannot be directly applied to the individual. ${ }^{34}$ With EU laws likely to turn into 'laws for

33. J. Jackson, The World Trading System, Cambridge, MA, The MIT Press (1997)

34. Unlike EU treaties and EU regulations, EU directives are not directly applicable. When passed they need a piece of legislation to turn them into national law. However, if the state fails to implement a directive within the time given by the EU then an individual can take the state to court for non-implementation. Therefore, originally, the directives do not presuppose the direct effect, but they acquire such an effect in the relation between the individual and the member state, as the latter maintains itself inert vis-à-vis the adoption of necessary measures for the application of such directives. On the other hand, it should be noted that, diversely, the descending vertical applicability of the direct effect does not take place, i.e., in the member state-individual way, insofar as the individual may not be forced to act in a certain manner even if his 
the individual', the member states must necessarily not only enforce them, but also frame a piece of national law that bears the standardised subject matter of the directives so that the content is passed onto individuals, bearing similar characteristics and conditions as any other domestic legislation.

The European Court of Justice (ECJ) has concentrated mainly on the question of whether domestic laws that are essential to give EU directives complete applicability to individuals have been framed or not. In some cases, however, it has been seen that provisions found within the EU directives have a direct effect, despite lacking immediate applicability. It must be noted that the ECJ does not acknowledge direct effect to a complete legislation but only to particular provisions. This is mainly because, unlike immediate applicability, direct effect is not based on the official nature of the legislation, but on the actual subject matter of a provision. ${ }^{35}$

This is in contrast to the system that operates in Mercosur. Authoritative powers of Mercosur's organisations remain strictly intergovernmental, as they do not have any supranational authority or direct effect. Directives from the MTC, decisions from the CMC and resolutions from the CMG are not directly applicable within the legal framework of each member state but must be ratified by them to come into force.

As we have analysed the situation of the ratification and applicability of all treaties and protocols signed among Mercosur member states and also with associated states from 1991 until the 15 July 2019, of all the 153 treaties already signed less than half were in force (74). More precisely, sixty-three were pending, ten derogated and six not in force, as Table 1 shows.

\section{Table $1 \quad$ Signed treaties (in force; not in force; pending; derogated)}

\begin{tabular}{lr} 
In force & 74 \\
\hline Not in force & 6 \\
\hline Pending & 63 \\
\hline Derogated & 10 \\
\hline Total of signed treaties (up to 15 July 2019) & 153
\end{tabular}

Elaborated by the present author, based on consultation at the website of the Ministry of Foreign Relations of Paraguay.

Source:www.mre.gov.py/tratados/public_web/

ConsultaMercosur.aspx. Retrieved on 15 July 2019.

Until 15 July 2019, there were eight treaties that were signed before 2000 for which ratification was still pending. Currently, the oldest is the Protocol on Promotion

or her own country of origin did not regulate the application of the directive.

35. D. Ventura \& A. Perotti, El processo legislativo del MERCOSUR, Uruguai, Konrad Adenauer Stiftung (2004). and Protection of Investments coming from Non-Mercosur State Parties, which was signed on 5 August 1994. The nature of 'secondary' law in Mercosur remained obscure until the early 1990s, and because of this, Articles 38-42 of the Protocol of Ouro Preto (POP) ${ }^{36}$ aimed at clarifying the situation. As per Article 40, for simultaneous applicability in all member states, the legal acts in Mercosur can be enforced only a month after the Administrative Secretariat announces their internalisation by all member states. ${ }^{37}$

Under Article 40, two matters are seen to tend to overlap, one pertaining to the applicability of Mercosur legislation as national law and the other to its applicability to individuals. This overlapping tends to produce three varying interpretations. The first interpretation (a) is highlighted in the third arbitration award that was passed in relation to the conflict between Brazil and Argentina in 2000 (in the matter of safeguards), where it was interpreted that the law can be enacted only after it has been incorporated into domestic law along with all the necessary notifications. Consequently, until then, the legislation remains effective, neither as a law for individuals nor as one for the states. Another interpretation (b) was highlighted in the fourth arbitration awarded on the conflict between Argentina and Brazil in 2001 on matters of poultry-related anti-dumping procedures. According to this interpretation, later adopted by many awards, the legislation cannot enter into force on individuals, since the procedure must start at the same time in all member states and the transposition along with all notification processes must be ready. This award also objectified that member states must internalise the legislation before a specific date and that if a member state failed to do so, then it can be challenged by the other members.

Some experts have contended that the third interpretation (c) takes Mercosur back towards the EU, with regard to its nature of directives. However, this is not entirely correct, as this interpretation clearly expresses that the legislation does not become effective until all the member states incorporate it into their national law. Therefore, it can be assumed that if a new legislation fails to be internalised by all the members, the previously existing legislation will remain effective and hold true for all member states (even those that have already internalised the legislation).

In this context, there are three points to be considered that would help to understand the legal nature of the secondary laws of Mercosur. The first point refers to the situation where differences between the interpretations become indistinct. This happens when all Mercosur member states have internalised the legislations. The differences become distinct only when one or more member states refuse to meet their obligations. The differences between the two interpretations also ease out

36. www.sice.oas.org/trade/mrcsr/ourop/ourop_e.asp.

37. In fact, it takes on average, between six to ten years for all member states to internalise the legislation. Concerning the recent EU-Mercosur trade agreement, signed on 28 June 2019, the road to ratification by all $28 \mathrm{EU}$ and 4 Mercosur countries also seems to be a long one. 
when, instead of restricting, the law provides rights to individuals, or a provision does not block the member states from enacting provisions that are more open in nature. The differences are exposed only when a new provision blocks individual rights. The second point to be considered is that dissimilarities between the interpretations become prominent during changes in the law of integration. As per the second interpretation, a new law can enter into force only after the hesitant member state agrees to move ahead and comply. As per the third interpretation, the opposite happens, and the new legislation becomes applicable when the most interested member state transmutes or transposes the law.

In summary, it is possible to identify two general problems concerning the legislative process of Mercosur. The first one refers to the internal incompatibility among the different levels of Mercosur law, as well as an external incompatibility concerning both the confrontation between Mercosur and member states' laws and Mercosur and international laws. The second problem refers to the difficulty of the internalisation of laws to national legal systems, which carries legal regional uncertainty and the absence of interpretation and the uniform application of Mercosur laws. ${ }^{38}$

\section{Mercosur and the EU's Impact}

The path to integration in Europe is quite different from that which leads to Mercosur. On 1 July 1968 only seventeen years after the signature of the European Coal and Steel Community (ECSC) Treaty (18 April 1951), the EU Customs Union was completed. In Mercosur, 'Lists of Exceptions' were envisaged to the Common External Tariff (CET), as instruments to allow member states to apply different import tax rates than those provided by the CET. Such lists persist although Mercosur has almost thirty years of existence. According to the Decision 26/15 about the List of Exception issued from the CMC, these lists should contain: 1) a maximum of 100 Mercosur Common Nomenclature (MCN) codes in the case of Argentina and Brazil, until 31 December 2021; 2) 649 codes in the case of Paraguay, until 31 December 2023; and 3) 225 codes in the case of Uruguay and Venezuela, until 31 December 2022. ${ }^{39}$

38. Ventura \& Perotti, above n. 35

39. The main sectors/products from each country: a) Argentina: chemicals and petrochemicals; pulp and paper; steel; shoes; b) Brazil: chemicals and petrochemicals, food, textiles, hygiene and cleaning products, leather and wood products; c) Paraguay: chemicals and petrochemicals, steel, food, tobacco; d) Uruguay: chemicals and petrochemicals. Up to now, there are still special regimes for sugar, automotive and textile products; the capital goods, telecommunication equipment and computing machinery sectors did not achieve the expected convergence. According to the Argentine newspaper Clarín: 'these exceptions have ended up piercing the common tariff until it becomes an empty shell. Today, about two out of three of the extra-regional imports of Mercosur are not governed by the CET, keeping the bloc away from the objective of greater integration. Thus, far from moving towards a cus-
Besides, member states may unilaterally modify, up to $20 \%$, the number of their respective exceptions every six months, according to Article 3 of the CMC Decision 58/10. According to Meyer:

While the bloc was created with the intention of incrementally advancing toward full economic integration, only a limited customs union has been achieved thus far. The group has also been plagued by internal disputes and frequent rule changes. Instead of serving as a platform for insertion into the global economy as originally envisioned, Mercosur has evolved into a more protectionist arrangement, shielding its members from external competition. ${ }^{40}$

The automotive sector, for example, is one of some key industries for both Argentina and Brazil economies, and since the creation of Mercosur it has been regulated through a parallel managed trade agreement. This is one kind of adaptation by Mercosur to maintain the viability of some areas related to trade. ${ }^{41}$

It is evident that Mercosur still has much work to do in evolving towards a 'perfect' customs union. The European experience is still a model that Mercosur sometimes even tries to replicate, especially in the building process and in the methodology of the implementation of several of its policies. The characteristics that corroborate the emulation of the EU model are revealed in Mercosur's content and form. Content is seen in the sectoral cooperation and integration between involved countries in Mercosur, such as Brazil and Argentina. Before the developments of the 1980s, countries in Mercosur had followed a policy of progressive liberalisation of trade and had pursued a possession goal, which envisaged the establishment of a common market for goods, services and capital and labour. Policymakers for Mercosur have also adopted a regulatory approach towards market integration, applying norms and market standards similar to those of the EU. Originally, the development of regional integration in Mercosur followed the EU's ambitious and gradual plan for economic integration, which had already yielded some benefits in the late 1990s. Moreover, Mercosur consolidated the involvement between Brazil and Argentina, dating back to the 1980s. Mercosur was an ambitious project of a full common market and with political and security policy coordination that was shown to be very dynamic, especially until 1998.

In terms of form, emulation is clearly revealed in the institutional framework underlying the EU model, with certain differences based on the distinctive characteris-

toms union, four separate customs territories remain in Mercosur, where intraregional trade remains subject to rules of origin.' Source: https://www.clarin.com/economia/hora-discutir-arancel-externocomun-mercosur_0_HJdKY8Xyz.html. Retrieved on 27 June 2019.

40. P.J. Meyer, 'Brazil-U.S. Relations', Congressional Research Service (CRS) Report of Congress, 11 February 2016, at: https://fas.org/sgp/ crs/row/RL33456.pdf. Retrieved on 4 November 2018, p. $12 \mathrm{ff}$.

41. N. Pose \& L. Bizzozero,'Regionalismo, economía política y geopolítica: tensiones y desafíos en la nueva búsqueda de inserción internacional del Mercosur', 28(1) Revista Uruguaya de Ciencia Política 249-278 (2019). 
tics of the region. The positions and the designs for each commission bear a close resemblance to those of the EU. The function of each commission or group, such as the $\mathrm{CMG}$, is the same as in the EU, yet again with certain differences in composition and regional characteristics. ${ }^{42}$ Resemblance to the EU can also be found in the realm of principles, such as those linked to human rights. In 2009 Mercosur created the Institute for Human Rights Policies, a regional organisation with the goal of providing technical cooperation and assistance in the formulation, design, implementation and articulation of public policies on human rights. ${ }^{43}$ In Europe, the EU Charter of Fundamental Rights ${ }^{44}$ entered into force on 1 December 2009 and became legally binding on the EU institutions and on national governments.

During the creation of Mercosur, the policymakers faced a high degree of uncertainty owing mainly to the lack of experience in the field of region building, aggravated by the rapidly changing context of the international community after the Cold War. The European model was elected, in the light of its achievements and success, in the hope that it would be applicable and that its creation would generate benefits comparable to those of the European model. According to Lenz, ${ }^{45}$ the concept of mimetic isomorphism describes Mercosur's adoption of the European model.

Owing to the degree of uncertainty and the availability of other models for regional integration, policymakers of Mercosur have chosen to emulate organisations that have shown experience, legitimacy and positive results in their development. During the institutional growth of Mercosur as a regional bloc, the concept of mimetic isomorphism has prevailed. Casola ${ }^{46}$ believes that isomorphism, also known as the institutional homogenisation of Mercosur, increases over time. In this sense, as both blocs market similar products and services, they are connected and could even become structurally equivalent in due course through repeated interactions. ${ }^{47}$ Schimmelfennig ${ }^{48}$ affirms that non-member actors imitate the EU because they recognise EU rules and policies as appropriate solutions to their own problems.

It was expected that uncertainty and indecisiveness would surface in dealing with regionalism, since the

42. L. Casola, Mercosur: From the Open Regionalism of 1990's to a Model of Post Liberal Integration. Paper Presented in the conference of New Latin American Development strategies in a changing international economic and political context, Aalborg University, Denmark (2008).

43. CMC Decision 14/09 issued on 24 July 2009. Source: http:// Mercosur.ippdh.Mercosur.int/wp-content/uploads/2014/04/ DEC_014-2009_PT_Inst-Politicas-Pub-Direitos-Humanos.pdf. Retrieved on 6 November 2018.

44. Adopted in 2000 and binding on EU countries since 2009.

45. T. Lenz, Problematizing the EU's model of Export to MERCOSUR: Strategies and Motivations. Paper Presented at the Garnet conference, 'The European Union in International Affairs', Brussels (2008).

46. Casola, above n. 42

47. The number of repeated interactions will certainly increase during the next years, as Mercosur and the EU signed, on 28 June 2019, a Free Trade Agreement, as we will see later.

48. F. Schimmelfennig, 'Europeanization beyond Europe', 10(1) Living Reviews in European Governance (2015). Source: http:// europeangovernance-livingreviews.org/Articles/lreg-2015-1. range of models during that time was limited. However, the 'power of attraction' of the EU model, which is composed primarily of legitimacy, combined with its history of achievements, culminated in strong factors over which policymakers deliberated not only in Brazil and Argentina, but also in other countries envisaging regionalism. It seems that it has become a common practice for policymakers to look upon the EU as an appropriate paradigm for the establishment of regionalism and customs unions, by virtue of the fact that it had become the first regional bloc to achieve the two, thus making it a worthy reference point.

Regional institutionalisation and regional market building have been the two core objectives of Mercosur and have been the focus of the EU's support, as shown during its active promotion of regionalism. Each objective has been parallel to the pursuit of long-term geopolitical interests of the EU, not only in the region, but also in other parts of the world. As seen, the EU has provided support in the development of Mercosur's regional institutionalisation and regional market building. To begin with, it directly supported Mercosur by reinforcing its personnel, lending staff and technical support, while initiating funds for Mercosur's pursuit of regional institutionalisation. As Kanner affirms,

Since the very inception of Mercosur, the European Union has strongly supported and continues to support integration in the Southern Cone. The number one proponent of regional integration in the world is the European Union, and this internationally respected organization announced in August 2002 that it will give $€ 200$ million to the countries of Mercosur between 2002 and $2006 .^{49}$

Besides, in the field of regional market building, the EU's support focused on the reciprocal liberalisation of trade and on the preparation of the region for economic and political association with other regional blocs and countries around the world.

Changes in agreements and objectives affected the support that was flowing to the region. Technical and financial assistance in the region was narrowly focused on economic integration and trade-related matters that were in the interest of the EU. ${ }^{50}$ Nevertheless, this option had little success, and the Union had begun to initiate alternative routes that could provide developments and improvements in its favour. ${ }^{51}$ These alternative routes have opened the path for a strategic partnership between the countries under Mercosur's control. As a result, on 4 July 2007, the European Commission proposed to launch a strategic partnership with Brazil at the first EU-Brazil Summit in Lisbon.

49. A. Kanner, 'European Union-Mercosur Relations: The Institutionalization of Cooperation', 1(8) Jean Monnet/Robert Schuman Paper Series 9 (October 2002).

50. Lenz, above n. 45.

51. A. Malamud, 'Presidentialism and Mercosur: A Hidden Cause for a Successful Experience', in Finn Laursen (ed.), Comparative Regional Integration: Theoretical Perspectives, Aldershot, Ashgate (2001). 
Although a bilateral set-up has advantages that are clearly not present in a bi-regional framework, the relationship of the EU and Mercosur was the focus for the creation of a regional market. Plans in this direction were in the hands of the Bi-Regional Negotiations Committee (BNC), where delegations from Mercosur and the EU held rounds of negotiations for more than two decades. More recently, the two blocs intensified the negotiations towards the signature of a Free Trade Agreement, as part of a broader association agreement between the two regions; finally, on 28 June 2019, Mercosur and the EU reached a trade agreement. According to the EU release,

The new trade framework - part of a wider Association Agreement between the two regions - will consolidate a strategic political and economic partnership and create significant opportunities for sustainable growth on both sides. ${ }^{52}$

\section{Mercosur in Practice - Successes and Failures}

As already mentioned, the purpose of the Treaty of Asunción of 26 March 1991 was the creation of a common market among Argentina, Brazil, Paraguay and Uruguay. It was to be gradually built through the implementation of a free-trade zone, which, in turn, was to be accomplished by 31 December 1994. A customs union - with the establishment of a $\mathrm{CET}^{53}$ - was to enter into force on 1 January 1995. In order to ensure fair competition among member states, barriers to trade among them were to be eliminated, and common trade policies towards third countries were to be adopted. In addition, macroeconomic and sectoral policies were to be harmonised.

A Trade Liberalisation Programme, in Annex 1 of the Treaty of Asunción, contained a schedule for the progressive, linear and automatic elimination of tariffs. This schedule started on 30 June 1991 and was wound up on 31 December 1994. Furthermore, the programme stipulated the possibility of excluding some products from the tariff reduction schedule, taking into consideration the differences in the levels of competitiveness. The numbers of goods excluded per member state were listed as follows: Argentina - 394, Brazil - 324, Paraguay -439 and Uruguay - 960. However, the number of goods per member state had to be reduced by $20 \%$ per year in order to finally achieve a free-trade zone by the end of 1994. The end of December 1995 was the deadline set for Paraguay and Uruguay. The previous deadline, end of December 1994, for the elimination of non-

52. http://trade.ec.europa.eu/doclib/press/index.cfm?id=2039\&title=EUand-Mercosur-reach-agreement-on-trade. Retrieved on 28 June 2019.

53. The CET started in 1995 to Argentina and Brazil, and in 1996 to Paraguay and Uruguay; it covered about $85 \%$ of all products and tariffs ranging from 0 until $20 \%$, with an average of $11 \%$. Lists of exceptions were allowed, for both sensitive goods and sectors. tariff barriers, was changed to June 1995. The Trade Liberalisation Programme was not fully respected, as some goods remained under an adaptation regime defined by Decision 5/94 of the CMC. Concerning the sensitive areas, the auto industry and sugar production had initially been left out of the Trade Liberalisation Programme, but both had, at the beginning of the 2000s, reduced and eliminated tariffs for intra-Mercosur trade. On 30 June 2000, a presidential communiqué was issued defending the participation of sugar in the CET and the free-trade zone but included no concrete proposals related to this matter. Despite being a major issue among the members of Mercosur, no significant improvement with regard to cooperation or integration was experienced.

Despite a condition of internal protectionism and restrictions, member states, especially during the 2000s, supported the creation of new organs, such as the Parliament, the Democracy Observatory, the Institute for Public Policy and Human Rights and the Social Institute and the Structural Convergence Fund. ${ }^{54}$ So far, despite the creation of these mechanisms to empower civil society and to decrease asymmetries, their effectiveness has largely been restricted. According to Espino:

the full democratization of decision-making areas in terms of social and gender issues has not yet been accomplished. This is true not only in consideration of the need for greater and wider participation of social actors, but also in terms of taking them into account when drafting proposals and evaluating the economic and commercial evolution of Mercosur. ${ }^{55}$

Thus, it seems that it would be more productive if member states had focused on the induction to the modernisation of the productive system and on institutional and sectoral reforms. An integration process necessarily involves productive modifications and efforts to adjustments of the production, investment and marketing plans of domestic enterprises. However, major differences in macroeconomic policies (fiscal, monetary and exchange rate ones) persisted, and member states remained protecting domestic groups related to sensitive sectoral policies.

Intrinsic characteristics of member states largely influence the integration process in Mercosur. Another recurrent problem of member states in Mercosur is related not only to the external environment, but also to their unstable domestic situation, both politically and

54. The social dimension of the bloc arose from them on, through the creation of some other mechanisms/institutions, such as: the Mercosur Institute for Public Policy and Human Rights (Decision CMC No. 40/04); the Constitutive Protocol of the Mercosur Parliament (2005); the Mercosur Social Summits (held since 2006); the Mercosur Democracy Observatory (Decision CMC No. 24/06); the Coordination Commission for Social Affairs Ministers (Decision CMC No. 45/10); and the Mercosur Social Participation Support Unit) (Decision CMC No. 65/10).

55. A. Espino, 'Impacting MERCOSUR's Gender Policies: Experiences, Lessons Learned, and the Ongoing Work of Civil Society in Latin America', in Forum International de Montreal (2008). 
economically. As internal problems arise, Mercosur is relegated to oblivion - member states seem to continue to act unilaterally, taking protectionist measures, showing disagreement and avoiding commitment to the established institutional structure of the bloc.

In addition, the current institutional framework of Mercosur does not oblige member states to coordinate their foreign policies. In sum, as Murcia ${ }^{56}$ affirms,

The institutionality of integration has great designs but the binding weakness of the agreements, the limited capacity of some Member States and the lack of will of the governments cause the failure of these integration models.

The absence of coordination in the macroeconomic realm is patent. As Canuto et al. ${ }^{57}$ concluded:

Under the customs union element of Mercosur, Argentina and Brazil apply the same general tariff on imports from third countries not party to the agreement. Yet, the experience since 1990 has been dozens of examples like the one of Brazil (but not Argentina) using antidumping to restrict steel imports from China. The lack of coordination in their applied trade policy toward third countries questions the extent to which they are really involved in a meaningful customs union. Under the FTA element of Mercosur, Argentina and Brazil apply a general tariff of zero on imports from each other. Yet, experience since 1990 has been dozens of examples like the one of Argentina imposing a separate, antidumping import restriction on imports from Brazil of fabrics.

In fact, macroeconomic coordination remains a challenge to Mercosur's member countries. In June 2019, Brazilian President Jair Bolsonaro suggested that Brazil and Argentina could have a single currency akin to the euro. Brazil's Economy Minister Paulo Guedes cited the example of Germany and said the nations would first need to make fiscal adjustments to reap the benefit of increased competitiveness from a common currency. ${ }^{58}$ Some hours later the Central Bank of Brazil issued a statement denying there are ongoing plans or even studies for a monetary union with Argentina. In fact, such a suggestion was perceived as a 'joke', 'unrealistic' and a 'delirium' in both countries, as they are facing discrepancies in their conditions - for instance, while Brazil currently has a buffer of international reserves that exceeds US $\$ 380$ billion, Argentina received the biggest

56. B.A. Murcia, 'Why Has Not Integration Been Possible in Latin America?', 22 September 2018. https://latinamericanpost.com/23467-whyhas-not-integration-been-possible-in-latin-america. Retrieved on 11 July 2019.

57. O. Canuto, C. Fleischhaker, P. Schellekens, P. Elle \& J. Remes, 'MERCOSUR is not really a free trade agreement, let alone a customs union' (2016).

58. https://www.bloomberg.com/news/articles/2019-06-07/a-commonbrazil-argentina-currency-a-distant-mirage-for-now. Retrieved on 2 July 2019. loan ever (US\$57 billion) from the International Monetary Fund (IMF) in 2018. ${ }^{59}$

Mercosur's institutions are unable to perform their original tasks. When problems arise, the executive branches of the member states come to determine dispute resolution. 'Regional' feeling among the member states, which should go beyond trade issues, is shown to be lacking in this scenario. Telò analyses a series of complications working against Mercosur's integration path and concludes that:

This situation not only shows the current level of disagreement between member states, but also clearly reveals the inability on behalf of Mercosur's institutions to provide a platform for resolving differences between member states. For all the above reasons, Mercosur appears weaker now than at the end of the twentieth century. ${ }^{60}$

Because of the frequent absence of supranational bodies, negotiations must be entered into by the President, who must show his or her capabilities in taking the particular issue in hand in order to bind the member states of the regional grouping in a proper, appropriate way. The Presidents often replace the Dispute Settlement Mechanism (DSM) ${ }^{61}$ of Mercosur. Under the functioning of the Protocol of Brasilia (1991) for the Settlement of Disputes in Mercosur, ten awards were delivered by the Mercosur ad hoc arbitration tribunals. Under the functioning of the Protocol of Olivos for the Settlement of Disputes in Mercosur (2002), two awards were delivered by ad hoc arbitration tribunals, and six awards were delivered by the permanent review tribunal (PRT). The PRT may act as the sole instance in certain cases; besides, it also reviews the decisions of the ad hoc arbitration tribunals. Most of the disputes that arrived at the PRT after its creation were exactly related to appeals, through the hearing of the cases in the first instance (awards from the ad hoc arbitration tribunals). The original intention of the creation of the PRT was to furnish a uniform interpretation of the body of legislation of Mercosur, including the establishment of a common jurisprudence, which could give greater legal certainty to the whole integration process.

Concerning the appeals specifically, Article 17 (2) of the Protocol of Olivos $(\mathrm{PO})^{62}$ explicitly states that the appeal is limited to questions of law, including the legal interpretations of the ad hoc arbitration tribunals. In addition, Article 22 of the same protocol affirms that the

59. https://www.theguardian.com/world/2018/sep/26/argentina-imfbiggest-loan. Retrieved on 2 July 2019.

60. M. Telò, European Union and New Regionalism: Regional Actors and Global Governance in a Post-hegemonic Era, Hampshire, England, Ashgate Publishing Limited., 2nd ed. (2007), at 174.

61. The DSM, or Dispute Settlement Mechanism, in the absence of a judicial body, is the closest representation of a supreme court or judicial institution in a regional bloc or other international organisation. Mercosur's DSM, originally created under the Treaty of Asunción, was later amended through the Protocol of Brasilia (PB) and upgraded with the Protocol of Olivos (PO).

62. www.internationaldemocracywatch.org/index.php/mercosur-treatiesand-protocols/116-protocolo-de-olivos. 
scope of the review is to confirm, modify or revoke the legal basis of decisions of the ad hoc arbitral tribunals. Thus, the role played by the review is restrictive, with exclusive analysis over the question of law and avoidance of debates over the questions of fact. The decision derived from the review will be definitive and will substitute the original one, delivered by the ad hoc arbitration tribunal.

Although the DSM of Mercosur apparently seems to have been successful in terms of dealing with the few disputes that have occurred since its creation, such efficiency is hardly apparent. First, and perhaps most importantly, the possibility of introducing forum choice for the settlement of disputes has brought a certain amount of discredit to the existent DSM. Forum choice adds another level of uncertainty and in many ways indicates distrust of the Mercosur DSM - neither of these aspects is beneficial for longer-term institutionalisation. In the dispute DS355 concerning 'Anti-dumping Measures on Imports of Certain Resins', Argentina requested consultations with Brazil directly in the World Trade Organization (WTO), bypassing the DSM of Mercosur, which shows its lack of legitimacy, even among members of the bloc. ${ }^{63}$ This was not the first time: in two other disputes in WTO at the beginning of the 2000s Brazil was the complainant and Argentina the respondent: DS190 (Argentina - Transitional Safeguard Measures on Certain Imports of Woven Fabric Products of Cotton and Cotton Mixtures Originating in Brazil) and DS241 (Argentina - Definitive Anti-Dumping Duties on Poultry from Brazil). ${ }^{64}$

As we analyse the increase in the participation of the private sector in the economies of the member states, we note that it has involved specific parties, concerning particular disputes. Most of these disputes have involved Argentina and Brazil; besides, the greatest part of the most important disputes, involving the private sectors, were solved according to an informal nature of decision-making processes, which has also been an intrinsic characteristic of the definition of integration policies within the bloc. This informal nature, based on political negotiation among high-level officials, has nat-

63. DISPUTE SETTLEMENT: DISPUTE DS355. Brazil - Anti-dumping Measures on Imports of Certain Resins from Argentina. 'On 26 December 2006, Argentina requested consultations with Brazil concerning antidumping measures applied by Brazil to imports of certain polyethylene terephthalate (PET) resins from Argentina. Argentina considers that the anti-dumping investigation conducted, the determination made and the duties imposed by Brazil are inconsistent. On 4 February 2008, the Chairman of the Panel informed the DSB that Argentina had indicated that on 29 January 2008, the Foreign Trade Chamber of Brazil had adopted a decision to suspend the application of anti-dumping duties on imports of PET resin from Argentina. Therefore, Argentina asked the Panel to suspend its work pursuant to Article 12.12 of the DSU. The Panel agreed to this request and suspended its work until further notice. Since the panel had not been requested to resume its work, pursuant to Article 12.12 of the DSU, the authority for the establishment of the panel lapsed as of 5 February 2009.' Source: https://www.wto.org/ english/tratop_e/dispu_e/cases_e/ds355_e.htm. Retrieved on 28 June 2019.

64. Source: https://www.wto.org/english/tratop_e/dispu_e/cases_e/ds 190_e.htm; https://www.wto.org/english/tratop_e/dispu_e/cases_e/ ds241_e.htm. urally had an impact over the DSM of Mercosur, gradually rendering it largely ignored. Another intrinsic characteristic of the dynamics in Mercosur is that often in the past disputes between member states have remained unsolved. The option for avoiding confrontation, which would threaten the political understanding among member states, has compelled them to come to a modus vivendi over these disputes, as a means of avoiding the likelihood of a deterioration in their relations.

As previously noted, the discussions, with regard to the main issues that have affected Mercosur, ever since its inception, have shown the option that the member states have taken in order to resolve disputes among themselves. They have tended to resort to Presidential Diplomacy, ${ }^{65}$ whereby only the heads of state handle the negotiations without much regard for the institutions established by the treaties that also created Mercosur. In addition, there are numerous other difficulties in improving an integration process when member states have a variety of structural differences and economic policies. It is no trivial task to reduce asymmetries and implement regulatory convergence, mainly during political and economic crises experienced by countries.

The power of the Presidents to resolve the disputes is generally brought about by the same power that they possess in the local setting of their countries. Considering this, negotiations undertaken do not generally conform to the standards of Mercosur. The DSM of Mercosur remains too highly politicised and lacks sufficient jurisdictional power on integration issues to guarantee its role in preventing and containing the violation of regulations. However, it seems that the creation of a supranational body would not change such politicisation. It would probably be ignored or underutilised, while Presidents or others high-ranking executive branch officials would take the responsibility to solve controversies themselves.

There are no legitimate institutions or mechanisms in Mercosur, such as the ECJ in the EU, to play a key role in upholding the rule of law. According to Malamud, four main actors are essential in ensuring the successful integration of the EU: (1) the national states, (2) the transnational transactors, (3) the European Commission and (4) the ECJ. The last two of the four components are absent in the experience of Mercosur, thus making the member states the main conductors of the process of integration. Increasing interdependence, in opposition to the cases of other regional groupings, has not led to an increase in demand for the general rules in Mercosur. Rather, the demands of these groupings are aimed at the promulgation of decisions that are of paramount impor-

65. Presidential Diplomacy is popular among the members of Latin America, and consequently, with the Mercosur countries. This is reflected in the fact that the regimes contained therein have often been described as being 'asymmetric, unbalanced, hyper-presidential or concentrationist'. In: A. Malamud, 'Presidential Diplomacy and the Institutional Underpinnings of Mercosur: An Empirical Examination', 40(1) Latin American Research Review 138-164 (February 2005). A combination of strong presidentialism and a weakness in political parties is a commonly occurring feature. 
tance to their operations. In relation to this, the Presidents have then responded to the increase in their tasks by becoming 'more accessible, more responsive, more effective, faster - than any other actors to reach decisions' ${ }^{66}$

In fact, legal and institutional transplants from the EU are not a guarantee of success in deepening the integration process. Eventually, the laws and institutions, copied in response to unreflective imitation, are likely either to be resisted or to remain unused. ${ }^{67}$ However, through the implementation of some adjustments, considering the peculiarities and the reality of Mercosur, the path of integration in the EU remains an example to be followed.

One of the adjustments to be highly considered is the elimination of the choice of forum in the settlement of disputes. To date, the Mercosur member states are free to submit their disputes to other courts, including the WTO and the International Court of Justice (ICJ). The DSM of Mercosur should have exclusive jurisdiction over all disputes concerning its legal order. Eventually, one could question whether the existence of the choice of forum in Mercosur is really a problem. It is not. At first, such a change would not avoid the persistence of Presidential Diplomacy. However, it would create a positive image and an impression of prestige and credibility around the Dispute Settlement System outside the bloc. The implementation of a reform would certainly be a demonstration of faith and trust in the development of the Mercosur integration process and would tackle the lack of political commitment on the part of the member states.

Mercosur resorted to Presidential Diplomacy in order to survive the crises it has experienced over the years. However, the positions taken by the member states when faced with risks have been turning into castles in the air, since they do not have the capacity to coordinate regulatory and macroeconomic policies.

The survival of the regional grouping is also heavily dependent on the outcome of political struggles in Argentina and Brazil as well as on the harmonisation of exchange rate policies between the two countries. To date, however, several periods of strong instability in all member states have been damaging and have therefore hindered any serious attempt to coordinate macroeconomic policies. Notably, the suspensions of Paraguay and Venezuela from Mercosur are examples of sources of more instability. ${ }^{68}$

66. Malamud (2005), above n. 65, at 139.

67. K.J. Alter, et al., 'Transplanting the European Court of Justice: The Experience of the Andean Tribunal of Justice', 60(3) American Journal of Comparative Law 629-665 (2012).

68. The Presidents of Argentina, Brazil and Uruguay decided to suspend Paraguay's rights to participate in Mercosur, at a summit held in Mendoza (Argentina). This suspension was related to the deposition of Paraguay's President by the country's Congress on 21 and 22 June 2012, and thus it was justified under the Protocol of Ushuaia. Paraguay argued that its suspension was invalid, since there was no kind of breakdown of democracy in the process of the impeachment of President Fernando Lugo (the then Vice-President, Federico Franco, took office in his place). Elections in Paraguay were held in April 2013, and

\section{Conclusion}

Despite several problems along its path, it is impossible to deny that one of the main characteristics of the international political and economic scene during the second half of the 20th century and at the beginning of the $21 \mathrm{st}$ has been economic and political integration. The model of the EU affected the subsequent efforts towards integration all around the world. While the EU represents the most advanced process of integration in the world, in other continents these experiences still remain reluctant as they face economic and political integration.

During the last few years several governments have chosen the path of growing unilateralism and trade tensions; some institutionalisation processes seem to stagnate, while others undergo reformulations, such as that which occurred with the North American Free Trade Agreement (NAFTA), which was renegotiated and replaced by the United States-Mexico-Canada Agreement (USMCA), as announced on 30 September 2018.

The fact is that institutionalisation processes cannot be expected to develop in similar and linear ways. Timetables are hard to follow, and the path of integration depends on different factors, such as cultural backgrounds, peculiarities and history intrinsically linked to the states involved in such a process. Mercosur could be considered as being one of the main regional organisations around the globe. Still, the fact that it has existed for almost thirty years is not necessarily a testament that the regional bloc has positioned itself well in the international community. Mercosur is not exempt from the problems that typically occur to every regional organisation. Despite some initial years of relative success, there are still problems and issues from within that could hinder the future development of this regional bloc. Besides, the institutionalisation of Mercosur, with the creation of several organs during the last decades, seems to be innocuous, as it apparently has not contributed to the advancement of the process of integration. The adoption of intergovernmentalism or supranationalism is not a sine qua non for the success of an integration bloc. In Mercosur's case, necessary conditions for the deepening of the integration process lie in the intrinsic characteristics of member states, which have, to date, prevented major qualitative changes in its institutions.

Taking a broader view, it can be seen that, from the beginning of the 2000s until 2019, most member states

Horacio Cartes became the new President. In December 2013, the Chamber of Deputies of Paraguay finally approved the protocol of the accession of Venezuela into Mercosur, and President Horacio Cartes manifested the intention of Paraguay of returning to the bloc. The official return occurred during the XLVI Summit of Mercosur in Caracas (Venezuela), in July 2014.Santos (2015, p. 50) affirmed that: 'the event that has revealed the aligning of the majority of presidents, acting as a sort of friends' club and emphasizing the political dimension above the legal and that 'what is relevant in this context is how these integration processes rely on the political will of the decision-makers even above institutionalism and, in this specific case, on the perception of peers of being aligned or not (i.e., like a friends' club with whom to share common projects).' In: S.C. Santos, 'Identity in Mercosur: Regionalism and Nationalism', 21 Global Governance 43-59 (2015). 
have chosen, when necessary, to return to protectionism. This position has become commonplace among Mercosur leaders, since some of them prefer to disregard the regulations of the bloc to fulfil domestic demands. Lack of coordination of trade policies and unilateral responses to political-economic shocks thus seem to persist indefinitely; it seems that the priority of almost all of the member states is, currently, to deal with domestic problems. The reality encapsulates concerns over widespread corruption in Brazil, ${ }^{69}$ Argentina's endless economic crisis, the scars of the temporary suspension of Paraguay, Venezuela's crisis and its suspension from the bloc, and Uruguay's systematic criticisms of Mercosur. All these factors expose the internal limits of regional integration in Mercosur, creating a wave of discouragement and pessimism about its future. Besides, externally, as a bloc, Mercosur has until only recently been criticised for the poor results obtained through the signing of free-trade agreements (FTAs) with other countries.

However, as Mercosur turns almost thirty years old, there are expectations of convergence and tolerance among member states, as proven at least towards the signature of the FTA with the EU: despite the domestic problems, Mercosur and the EU concluded, on 28 June 2019 , negotiations on the trade agreement between the blocs. ${ }^{70}$ Discussions lasted two decades and were indeed intensified since 2016. The free-trade area will be one of the largest in the world: $25 \%$ of world GDP and a market of 780 million people. The agreement, in principle, covers seventeen areas: 1. Trade in Goods; 2. Rules of Origin; 3. Customs and Trade Facilitation; 4. Trade Remedies; 5. Sanitary and Phytosanitary Measures (SPS); 6. Dialogues; 7. Technical Barriers to Trade (TBT); 8. Services and Establishment; 9. Public Procurement; 10. Competition; 11. Subsidies; 12. Stateowned Enterprises; 13. Intellectual Property Rights, including Geographical Indications; 14. Trade and Sustainable Development; 15. Transparency; 16. Small and Medium-sized Enterprises; and 17. Dispute Settlement. It is already considered as Mercosur's most important achievement in its external relations, and it strongly indicates that both blocs stand for a rule-based trade system. As EU Trade Commissioner Cecilia Malmström declared, 'We reinforce multilateral agreements whilst others rip them up', referring to Donald Trump's administration. ${ }^{71}$

It is to be seen whether such an agreement will have, as one of its possible spill over effects, the upgrading of regulatory, sectorial and macroeconomic coordination and greater convergence in trade policies among Merco-

The former Brazilian president Luiz Inácio Lula da Silva, himself, has been convicted of corruption. He is serving a 12-year jail term. Operation Car Wash is still in progress, which may be the biggest corruption scandal in history. See: https://www.theguardian.com/world/2017/ jun/01/brazil-operation-car-wash-is-this-the-biggest-corruptionscandal-in-history. Retrieved on 8 November 2018.

70. The signatures of other FTAs are expected in the months to come.

71. See: https://foreignpolicy.com/2019/07/03/while-trump-isolates-u-sits-lets-make-a-deal-for-the-rest-of-the-world-trade-fta-mercosur-eu/. Retrieved on 15 July 2019 sur countries. ${ }^{72}$ As Marcos Troyjo, Brazil's deputy minister of the economy, in charge of foreign trade, affirmed, the Mercosur-EU agreement will 'give us the opportunity to press the reset button on Mercosur'. ${ }^{73}$
72. Before the conclusion of such an agreement, surprisingly, Mercosur had only signed FTAs with the following: Israel, in December 2007 (in force); Egypt, in August 2010 (in force); and the State of Palestine, in December 2011 (not in force).

73. See: https://www.poder360.com.br/economia/acordo-com-uniao-euro peia-permite-reset-no-mercosul-diz-marcos-troyjo. Retrieved on 15 July 2019. 


\section{Annex I}

Partial Scope Agreement of Economic Complementarity

(PS.ECA) Currently in Force

No 2 Brazil Uruguay

No 6 Argentina Mexico

No 13 Argentina Paraguay

No 14 Argentina Brazil

No 16 Argentina Chile

No 18 Argentina Brazil Paraguay Uruguay

No 22 Bolivia Chile

No 23 Chile Venezuela

No 24 Chile Colombia

No 33 Colombia Mexico Venezuela

No 35 Argentina Brazil Chile Paraguay Uruguay

No 36 Argentina Bolivia Brazil Paraguay Uruguay

No 38 Chile Peru

No 40 Cuba Venezuela

No 41 Chile Mexico

No 42 Chile Cuba

No 46 Cuba Ecuador

No 47 Bolivia Cuba

No 49 Colombia Cuba

No 50 Cuba Peru

No 51 Cuba Mexico

No 53 Brazil Mexico

No 54 Argentina Brazil Mexico Paraguay Uruguay

No 55 Argentina Brazil Mexico Paraguay Uruguay

No 57 Argentina Uruguay

No 58 Argentina Brazil Paraguay Peru Uruguay

No 59 Argentina Brazil Colombia Ecuador Paraguay Uruguay Venezuela

No 60 Mexico Uruguay

No 62 Argentina Brazil Cuba Paraguay Uruguay

No 63 Uruguay Venezuela

No 64 Paraguay Venezuela 
No 65 Chile Ecuador

No 66 Bolivia Mexico

No 67 Mexico Peru

No 68 Argentina Venezuela

No 69 Brazil Venezuela

No 70 Bolivia Cuba Venezuela Nicaragua

No 71 Cuba Panama

No 72 Argentina Brazil Colombia Paraguay Uruguay

No 73 Chile Uruguay

Source: http://Mercosur.aladi.org/nsfaladi/textacdos.nsf/vacewebp. Retrieved on 27 June 2019. 


\section{Annex II}

Institutional Landmarks - Mercosur's History of Integra-

tion

\begin{tabular}{|c|c|c|}
\hline Date & Agreement & Title \\
\hline 28 June 2019 & Mercosur - EU & $\begin{array}{l}\text { Signing of the Free Trade Agreement between Mercosur and the European } \\
\text { Union. }\end{array}$ \\
\hline 17 June 2018 & Mercosur & $\begin{array}{l}\text { Signing of the Framework Agreement between Mercosur and the Financial } \\
\text { Fund for the Development of the Plata Basin (FONPLATA). }\end{array}$ \\
\hline 20 July 2017 & Mercosur & $\begin{array}{l}\text { Signing of the Memorandum of Understanding for the exchange of docu- } \\
\text { ments to clarify serious human rights violations. }\end{array}$ \\
\hline 01 December 2016 & Mercosur & Suspension of Venezuela. \\
\hline 17 July 2015 & Mercosur & $\begin{array}{l}\text { Signature of a new Bolivia's Protocol of Accession to Mercosur. Paraguay was } \\
\text { suspended from the bloc during the signature of the previous protocol. } \\
\text { Although it was suspended, Paraguay was still a full member of the group, } \\
\text { and according to Art. } 20 \text { of the Treaty of Asunción, it should also approve the } \\
\text { admission of a new partner. The procedure of ratification is not necessary in } \\
\text { Argentina, Uruguay and Venezuela, whose parliaments have already ratified } \\
\text { the first protocol. }\end{array}$ \\
\hline 16 July 2015 & Mercosur & New exceptions to the Common External Tariff (CET). \\
\hline 18 December 2013 & Mercosur & Paraguay approved the admission of Venezuela to Mercosur. \\
\hline 05 April 2013 & Mercosur & Venezuela adopted Mercosur Common Nomenclature (MCN). \\
\hline 26 December 2012 & Mercosur & Liberalisation of intra-regional trade with Venezuela. \\
\hline 07 December 2012 & Mercosur & Signature of Bolivia's Protocol of Accession to Mercosur. \\
\hline 21 November 2012 & Mercosur & Argentina approved the Mercosur Customs Code (MCC). \\
\hline 30 July 2012 & Mercosur & Venezuela's Mercosur incorporation. \\
\hline 29 June 2012 & Mercosur & Restructuring of the Common Market Group (CMG). \\
\hline 29 June 2012 & Mercosur & New exceptions to the Common External Tariff (CET). \\
\hline 29 June 2012 & Mercosur & Suspension of Paraguay. \\
\hline 20 December 2011 & Mercosur & $\begin{array}{l}\text { Mercosur CMC Decision } 38 / 11 \text { created an ad hoc working group to enable } \\
\text { the Republic of Ecuador to be fully incorporated into the bloc. }\end{array}$ \\
\hline 20 December 2011 & Mercosur & $\begin{array}{l}\text { Signature of the Protocol of Montevideo on Commitment to Democracy in } \\
\text { Mercosur (Ushuaia II). It established the participation of Brazil, Argentina, Par- } \\
\text { aguay, Uruguay, Chile, Bolivia, Colombia, Ecuador, Peru and Venezuela. }\end{array}$ \\
\hline 20 December 2011 & Mercosur & $\begin{array}{l}\text { Mercosur adopted a mechanism to generate new exceptions to the Common } \\
\text { External Tariff (CET). }\end{array}$ \\
\hline 28 September 2011 & Mercosur & $\begin{array}{l}\text { Approval of LAIA - Mercosur provisions relating to rules of origin and special } \\
\text { import duties. }\end{array}$ \\
\hline 16 December 2010 & Mercosur & $\begin{array}{l}\text { Identification of priority issues and creation of the institutional mechanism } \\
\text { called 'High General Representative of Mercosur'. }\end{array}$ \\
\hline 16 December 2010 & Mercosur & $\begin{array}{l}\text { Specifications for the use of temporary exceptions to the CET and advance- } \\
\text { ment in the consolidation programme of the Customs Union. }\end{array}$ \\
\hline 16 December 2010 & Mercosur & $\begin{array}{l}\text { Mercosur developed regulations concerning the social dimension of integra- } \\
\text { tion. }\end{array}$ \\
\hline
\end{tabular}




\begin{tabular}{|c|c|c|}
\hline Date & Agreement & Title \\
\hline 02 August 2010 & Mercosur & Mercosur decisions oriented towards the improvement of the Customs Union. \\
\hline 07 December 2009 & Mercosur & $\begin{array}{l}\mathrm{CMC} \text { extended the use of drawback and of temporary admission in intra- } \\
\text { regional trade. }\end{array}$ \\
\hline 07 December 2009 & Mercosur & CMC defined and extended exceptions to the CET. \\
\hline 24 July 2009 & Mercosur & Unification of rules of origin. \\
\hline 24 July 2009 & Mercosur & $\begin{array}{l}\text { New details in the utilisation of local currencies in intra-Mercosur trade trans- } \\
\text { actions. }\end{array}$ \\
\hline 15 December 2008 & Mercosur & Postponed definitions regarding the common external trade policy. \\
\hline 30 June 2008 & Mercosur & Mercosur attempted to strengthen its productive complementarity. \\
\hline 18 January 2007 & Mercosur & $\begin{array}{l}\text { The first pilot projects to be financed by the Structural Convergence Fund } \\
\text { were approved. }\end{array}$ \\
\hline 04 July 2006 & Mercosur & $\begin{array}{l}\text { The accession to the integration scheme by the Bolivarian Republic of Vene- } \\
\text { zuela was signed by its President and Presidents of the four member states of } \\
\text { Mercosur. }\end{array}$ \\
\hline
\end{tabular}

09 December $2005 \quad$ Mercosur Signature of the Constitutive Protocol of the Parliament of the Mercosur: crea-
tion of the Mercosur Parliament.

02 January $2004 \quad$ Mercosur
The Olivos Protocol (PO) finally entered into force. Prior to 1 January 2004, the applicable instruments were Annex III of the Treaty of Asunción and the Protocol of Brasilia.

06 October $2003 \quad$ Mercosur

Creation of the Committee of Permanent Representatives of Mercosur, as a standing body to assist the CMC and the Pro Tempore President.

18 June $2003 \quad$ Mercosur

XXIV Meeting of the CMC, when two proposals were presented: creation of an Institute for Monetary Co-operation in Mercosur and the conclusion of a 'Programme for the Consolidation of the Customs Union and the launch of the Common Market'.

06 December $2002 \quad$ Mercosur

XXIII Meeting of the CMC, for the discussion of the internalisation of norms from Mercosur, regulation of the dispute settlement system and the gradual transformation of the administrative secretariat into a technical one.

11 November $2002 \quad$ Argentina - Brazil PS.ECA 14
The 31st Additional Protocol, internalised by both countries, incorporated the Treaty of bilateral integration formalised in LAIA as PS.ECA 14, as a new 'Agreement on Common Automotive Policy between the Republic of Argentina and the Federative Republic of Brazil'.

18 February $2002 \quad$ Mercosur

Institutional strengthening: III Extraordinary Meeting of the CMC: Presidents signed the Protocol of Olivos, which, once ratified (1 January 2004), replaced the Brasilia Protocol for the Settlement of Disputes. The Protocol of Olivos provided different mechanisms to settle disputes between member states related to the interpretation, application and breach of the Treaty of Asunción and subsequent treaties, decisions or measures taken under the Treaty of Asunción. The mechanisms are a) direct negotiations (Chapter IV), b) an optional mediation procedure before the Mercosur Group (Chapter V), c) ad hoc arbitration (Chapter VI) and d) proceedings before the Permanent Review Court (Chapter VII). Letters ' $a$ ' and ' $b$ ' are known as pre-trial mechanisms. The Protocol of Olivos provided the aforementioned Permanent Review Tribunal, which was officially installed more than two years later (in August 2004), and its role was to settle disputes submitted to it by member states and to give advisory opinions on legal questions that might arise. Besides, the Protocol of Olivos also established the recognition of the possibility that the applicant member state can choose and submit the dispute to the Dispute Settlement Body (DSB) of the World Trade Organization (WTO) or to other mechanisms provided by preferential trading schemes of which they are parties. 


\begin{tabular}{|c|c|c|}
\hline Date & Agreement & Title \\
\hline 20 December 2001 & Mercosur & $\begin{array}{l}\text { Revision of some of the deadlines initially set for the 'Relaunching of Merco- } \\
\text { sur'. }\end{array}$ \\
\hline 07 April 2001 & Mercosur & $\begin{array}{l}\text { Through Decision 1/01, the CMC authorised Argentina to apply exceptional } \\
\text { and temporary (until } 31 \text { December 2002) import duties of products originating } \\
\text { from non-member countries. }\end{array}$ \\
\hline 14 December 2000 & Mercosur & $\begin{array}{l}\text { CMC extended the deadlines for various decisions made during the previous } \\
\text { meeting and set a new regime of exceptions to the CET. }\end{array}$ \\
\hline 29 June 2000 & Mercosur & $\begin{array}{l}\text { 'Relaunching of Mercosur': CMC issued several decisions aiming to schedule } \\
\text { the removal of restrictive measures and domestic regulations that caused dis- } \\
\text { tortionary effects on intra-regional trade. }\end{array}$ \\
\hline 08 December 1998 & Mercosur & $\begin{array}{l}\text { Through Resolution } 77 / 98 \text {, the CMG established the mutual recognition and } \\
\text { equivalence of control systems. }\end{array}$ \\
\hline 24 July 1998 & Mercosur & $\begin{array}{l}\text { Signature of Protocol of Ushuaia on Democratic Commitment in Mercosur, } \\
\text { the Republic of Bolivia and the Republic of Chile. }\end{array}$ \\
\hline 16 April 1998 & Mercosur & $\begin{array}{l}\text { Framework Agreement for the creation of a free-trade area Mercosur - } \\
\text { Andean Community (CAN): The Framework Agreement could not lead imme- } \\
\text { diately to the negotiation stipulated therein. Consequently, Brazil, on the one } \\
\text { hand, and Colombia, Ecuador, Peru and Venezuela, on the other, agreed by } \\
\text { the 39th Economic Complementation Agreement (ECA) of LAIA, to establish } \\
\text { fixed preference margins as a first step towards the creation of a free-trade } \\
\text { area between the Andean Community and Mercosur. On } 31 \text { March } 2000 \text { a } \\
\text { second negotiation was concluded, this time between the countries of the } \\
\text { Andean Community and Argentina, with the purpose of signing another LAIA } \\
\text { agreement. Concerning Bolivia, the 36th ECA of LAIA of } 17 \text { December } 1996 \\
\text { set a programme to implement a free-trade area between this country and } \\
\text { Mercosur. }\end{array}$ \\
\hline 25 June 1996 & Mercosur & $\begin{array}{l}\text { Economic Complementation Agreement Mercosur-Chile: (on } 1 \text { October 1996) } \\
\text { came into force. This agreement constituted the first free-trade area between } \\
\text { Mercosur and a third country. }\end{array}$ \\
\hline 15 December 1995 & Mercosur & $\begin{array}{l}\text { Mercosur-EU: Signing of the Interregional Framework Co-operation Agree- } \\
\text { ment between the European Community and its Member States, on the one } \\
\text { hand, and the Southern Common Market and its Party States, on the other- } \\
\text { Joint Declaration on political dialogue between the European Union and Mer- } \\
\text { cosur. The treaty institutionalised political dialogue at the level of heads of } \\
\text { state and set a commitment to address the preparatory work for the establish- } \\
\text { ment of a future free-trade area between the two regions. }\end{array}$ \\
\hline 05 August 1995 & Mercosur & $\begin{array}{l}\text { 'Mercosur Action Program Until the Year } 2000 \text { ': through Decision } 9 / 95 \text {, the } \\
\text { CMC defined the intent of deepening the integration process and proceeded } \\
\text { towards the creation of a common market. Final and intermediate goals were } \\
\text { raised: consolidation of the free-trade area and of the conditions of intra- } \\
\text { regional competition; improvement of the common trade policy; legal and } \\
\text { institutional development; services; communications; transport and infrastruc- } \\
\text { ture; tourism; financial affairs; tax issues; macroeconomic policies; Mercosur } \\
\text { external relations; and global dimension of integration (environment, culture, } \\
\text { health, education, science and technology, intellectual property, police coop- } \\
\text { eration and migration). }\end{array}$ \\
\hline
\end{tabular}




\begin{tabular}{|c|c|c|}
\hline Date & Agreement & Title \\
\hline 17 December 1994 & Mercosur & $\begin{array}{l}\text { Protocol of Ouro Preto (Additional Protocol to the Treaty of Asunción): it } \\
\text { adapted the original structure of Mercosur in order to consolidate the customs } \\
\text { union, with the aim of moving towards the Common Market. It also defined a } \\
\text { scheme of final adjustment to the customs union with the extension of the } \\
\text { transitional period, until } 1 \text { January } 1999 \text { for Argentina and Brazil, and until } \\
1 \text { January } 2000 \text { for Paraguay and Uruguay. The Protocol of Ouro Preto also } \\
\text { raised the structure of Mercosur, with the creation of new organs: a) the Mer- } \\
\text { cosur Trade Commission (MTC, issuing directives), subject to the CMG and } \\
\text { responsible for ensuring the application of common trade policy instruments } \\
\text { agreed by the member states for the functioning of the customs union; b) the } \\
\text { Joint Parliamentary Committee (JPC); and c) the Economic-Social Consultative } \\
\text { Forum (ESCF). The protocol also augmented the powers of the Administrative } \\
\text { Secretariat of Mercosur (ASM). It entered into force on } 15 \text { December 1995. }\end{array}$ \\
\hline 09 December 1994 & Mercosur & $\begin{array}{l}\text { Through Decision 22/94 at the VII Meeting of the CMC, the customs union } \\
\text { entered into force: the CET began with eleven different levels of aliquots } \\
\text { (from } 0 \% \text { to } 20 \% \text { ); it defined a period of convergence on sectors such as cap- } \\
\text { ital goods, telecommunication equipment and computing machinery; submis- } \\
\text { sion of lists of exceptions to the CET was allowed; temporary exceptions were } \\
\text { allowed for each member state; definition of special regimes for sugar, auto- } \\
\text { motive and textile products; approval of a rule of mutual tolerance to a tariff } \\
\text { increase of three points, initially until } 31 \text { December } 2000 \text {. }\end{array}$ \\
\hline 14 October 1994 & Mercosur & Extension of interregional trade restrictions. \\
\hline 01 July 1993 & Mercosur & Integrated Border Management. \\
\hline 17 December 1991 & Mercosur & $\begin{array}{l}\text { The Protocol of Brasília for the Settlement of Disputes was signed in compli- } \\
\text { ance with Art. } 3 \text { and Annex III of the Treaty of Asunción. It adopted a settle- } \\
\text { ment of disputes system for the period of transition, and it was provided that } \\
\text { the system would end in December 1994. A General Proceeding for Claims } \\
\text { before the Mercosur Trade Commission was later annexed to the Protocol of } \\
\text { Ouro Preto, in } 1994 \text {. }\end{array}$ \\
\hline 29 November 1991 & Mercosur & $\begin{array}{l}\text { Economic Complementation Agreement (ECA) number 18: To comply with } \\
\text { the most-favoured-nation of the Treaty of Montevideo (1980), member states } \\
\text { signed the ECA } 18 \text { in which they transcribed the commitments made at the } \\
\text { Treaty of Asunción and protocolised it in the LAIA. }\end{array}$ \\
\hline 26 March 1991 & Mercosur - ECA 18 & $\begin{array}{l}\text { Signature of the Treaty of Asunción, establishing the Common Market of the } \\
\text { South between the Republics of Argentina, Brazil, Paraguay and Uruguay. }\end{array}$ \\
\hline 20 December 1990 & $\begin{array}{l}\text { Argentina - Brazil ECA } \\
14^{*}\end{array}$ & $\begin{array}{l}\text { Argentina and Brazil signed the Economic Complementation Agreement (ECA) } \\
14 \text { under the auspices of the Latin American Integration Association (LAIA). It } \\
\text { formalised the goals set by the Buenos Aires Act of } 6 \text { July 1990. This agree- } \\
\text { ment consolidated all previous bilateral trade agreements into a single text, } \\
\text { such as the economic complementation agreements numbers } 7 \text { (capital) and } \\
12 \text { (food industry) and agreements in areas such as nuclear cooperation and } \\
\text { the automotive industry. The ECA } 14 \text { defined the process of trade liberalisa- } \\
\text { tion to continue until } 31 \text { December 1994, especially concerning the progres- } \\
\text { sive tariff reduction (linear and automatic reductions), the decrease of the lists } \\
\text { of exceptions and the elimination of non-tariff barriers. }\end{array}$ \\
\hline
\end{tabular}




\begin{tabular}{|c|c|c|}
\hline Date & Agreement & Title \\
\hline 06 July 1990 & Argentina - Brazil & $\begin{array}{l}\text { Deepening of the Integration Process between Argentina and Brazil: Presi- } \\
\text { dents signed the Buenos Aires Act, in order to anticipate deadlines of the Inte- } \\
\text { gration Treaty of } 1988 \text {. They decided to establish a common market between } \\
\text { the two countries, 'which must be definitively shaped by December 31, 1994'. }\end{array}$ \\
\hline 06 July 1990 & Argentina - Brazil & $\begin{array}{l}\text { Signature of the Treaty for the Establishment of the Statute for Bi-national } \\
\text { Companies Brazil-Argentina: it granted national treatment to companies } \\
\text { located in the territory of any of the two countries subject to some require- } \\
\text { ments. The instruments of ratification were exchanged on the occasion of the } \\
\text { meeting of the CMC on } 26 \text { and } 27 \text { June } 1992 \text { in Las Lenas, Argentina. }\end{array}$ \\
\hline 29 November 1988 & Argentina - Brazil & $\begin{array}{l}\text { Treaty of Integration, Co-operation and Development between Argentina and } \\
\text { Brazil: to definitively consolidate the process of integration between the two } \\
\text { countries. The Treaty defines, as an ultimate goal, the creation of a common } \\
\text { market. As a preparatory stage, the objectives were to remove tariff barriers } \\
\text { within a maximum term of ten years and to achieve macroeconomic policy } \\
\text { harmonisation. }\end{array}$ \\
\hline 29 July 1986 & Argentina - Brazil & $\begin{array}{l}\text { Signature of the Minutes for the Brazilian-Argentinean Economic Integration } \\
\text { and Co-operation (Programa de Integración Mercosur Cooperación Económi- } \\
\text { ca-PICE). This, then, saw the beginning of the integration and economic } \\
\text { cooperation process between the Federate Republic of Brazil and the Republic } \\
\text { of Argentina, which was based on the principles of gradualism, equilibrium } \\
\text { and symmetry in order to allow for a progressive adaptation of the inhabitants } \\
\text { and the companies in each member state to the new competition and eco- } \\
\text { nomic legislation conditions. }\end{array}$ \\
\hline
\end{tabular}

* The Treaty of Montevideo II (1980) makes the distinction between 'Regional scope agreement' and 'Partial scope agreement'. Article 6 of the Treaty establishes that 'Regional scope agreements are those in which all member countries participate. They shall be drawn up within the framework of the objectives and provisions of the present Treaty, and may refer to the same matters and include those instruments foreseen for the partial scope agreements provided for in the third section of the present chapter', while Article 7 establishes that 'Partial scope agreements are those wherein all member countries do not participate. These agreements shall tend to create the conditions necessary to deepen the regional integration process by means of their progressive multilateralization. Rights and obligations to be established in partial scope agreements shall exclusively bind the signatory member countries or those adhered thereto'.

Source: http://wits.worldbank.org/GPTAD/PDF/archive/LAIA-ALADI.pdf.

Elaborated by the present author. 


\section{Annex III}

Main Provisions of Treaties

\begin{tabular}{ll} 
Treaty of Asunción (1991) & $\begin{array}{l}\text { Signed by the four founding members: Argentina, Brazil, Paraguay and Uru- } \\
\text { guay. This serves as the legal document that forms the basis of the establish- } \\
\text { ment of Mercosur. }\end{array}$ \\
\hline Brasilia Protocol on Dispute Settlement (1991) & $\begin{array}{l}\text { The Brasilia Protocol on Dispute Settlement introduced an arbitration mecha- } \\
\text { nism for dispute settlement, which became the first regional integration } \\
\text { scheme in the Latin American continent. }\end{array}$ \\
\hline Ouro Preto Protocol (1994) & $\begin{array}{l}\text { The Ouro Preto Protocol is considered to be the present constitution of Mer- } \\
\text { cosur. It recognises the legal existence of the bloc under international law. } \\
\text { Aside from this, it also lays out most of the current make-up of Mercosur and } \\
\text { gives it authority to negotiate agreements with third parties. }\end{array}$ \\
\hline Olivos Protocol on Dispute Settlement (2002) & $\begin{array}{l}\text { The Olivos Protocol on Dispute Settlement builds on previous protocols. It was } \\
\text { responsible for the creation of the Permanent Review Tribunal (TPR) as well as } \\
\text { a post-decision control mechanism for Mercosur. }\end{array}$ \\
\hline $\begin{array}{l}\text { Creation of Funds for the Structural Convergence } \\
\text { of Mercosur (FOCEM) (2005) }\end{array}$ & $\begin{array}{l}\text { The main objectives of FOCEM are: a) financing programmes to promote } \\
\text { structural convergence; b) increasing competitiveness and promoting social } \\
\text { cohesion in less developed countries and regions; c) supporting the function- } \\
\text { ing of the institutional framework; d) and strengthening the integration pro- } \\
\text { cess. }\end{array}$
\end{tabular}

Elaborated by the present author. 